\title{
Bölgesel Kalkınma Politikalarındaki Dönüşüm: Yeni Bölgecilik Yaklaşımı ve Türkiye Yansımaları
}

\section{Transformation in Regional Development Policy: New Regionalism Approach and It's Reflections in Turkey}

\author{
Asena Gizem Yiğit, ${ }^{a}$ Selen Işık Maden ${ }^{\text {b* }}$ \\ ${ }^{a}$ Araș. Gör., Süleyman Demirel Üniversitesi, İktisadi ve İdari Bilimler Fakültesi, Bankacılık ve Finans Bölümü, 32100, Isparta/Türkiye. \\ ORCID: 0000-0003-4064-8250

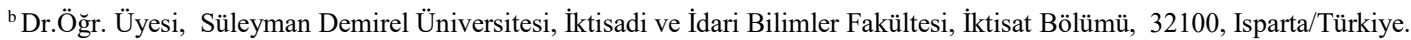 \\ ORCID: 0000-0002-3998-855X
}

\section{MAKALE BİLGİSI}

Makale Geçmişi:

Başvuru tarihi: 02 Mayıs 2018

Düzeltme tarihi: 23 Eylül 2018

Kabul tarihi: 27 Kasim 2018

Anahtar Kelimeler:

Yeni bölgecilik

Geleneksel bölge yaklaşımı

Bölgesel kalkınma
ÖZ

Kalkınmanın dinamik bir olgu olması, zaman içinde hedef ve stratejilerin de değişmesine neden olmaktadır. II. Dünya Savaşı'na kadar uzanan dönemde iktisadi analizlerde mekân yerine zaman kavramına önem verilmiştir. Kalkınmanın temelinde yer alan bölgesel kalkınma, özellikle II. Dünya Savaşı sonrasında mekânlar arasında gözlemlenen kalkınma farklılıkları nedeniyle iktisatçıların ve politika yapıcıların dikkatlerini çekmiștir. Mekânsal temelli olarak açıklanmaya çalışılan bu eşitsizlik uygulanan politik yaklaşımlarda da önemli dönüşümleri beraberinde getirmiştir. Merkeziyetçilikten uzaklaşarak giderek yerelleşmeye dönük geliştirilen teorik ve politik yaklaşımlar hem yeni kuramların hem de yeni kurumsal oluşumların ortaya çıkmasını sağlamıştır. Bu çalışmada Geleneksel Bölgecilikten, Yeni Bölgecilik akımına geçişte yaşanan teorik dönüşümler incelenirken bu dönüşümlerin Türkiye'deki bölgesel kalkınma politikaları üzerinde yaratmış olduğu yansımalar ortaya konmaktadır.

\section{ARTICLE INFO}

\section{Article history:}

Received 02 May 2018

Received in revised form 23 September 2018

Accepted 27 November 2018

Keywords:

New regionalism

Traditional Regional Approach

Regional Development

\begin{abstract}
A B S T R AC T
As a result of development's being a dynamic concept, aims and strategies differ globally within time. In the period that extending to the $2^{\text {nd }}$ World War, in economic analysis the concept of time emphasized instead of the concept of location. Regional development which takes places in the center of development, has took the attention of economists and politicians because of observed development difference across locations in post period of $2^{\text {nd }}$ World War. This inequality which is tried to be explained in basis of location, brought important transformations in political approachs applied. The theoric and political approachs which is developed intended for localization by moving away from centralisation, provided arising of both new theories and new institutions. In this study, on the one hand, the theoretical transformation which experienced during the transition period from Traditional Regionalism to the New Regionalism is being analysed, on the other hand reflections which this transition has created upon regional development policy in Turkey are revealed.
\end{abstract}

\section{Giriş}

Bölgelerarası gelişmişlik farklılıkları, hem gelișmiş hem de gelişmekte olan ülkeler için yıllar boyunca üzerinde dikkatle çalışılması gereken ortak bir sorunu ifade etmektedir. $\mathrm{Bu}$ durum, bölgesel kalkınma kavramını doğurmuş ve her ülke farklı yaklaşım ve araçlarla bu evrensel alana dâhil olmuştur. Alan ekonomisi olarak da bilinen bölgesel kalkınma kavramı, zaman içinde giderek daha da önem kazanmıştır.

Geleneksel bir anlayışla fiziksel sınırlar içinde kalan yer olarak düşünülen alan kavramı, küreselleşmenin hız kazanmasıyla birlikte içeriğini genişleterek çok da farklı anlamlar kazanmaya başlamıştır. Bu dönüşüm sürecinde bölgesel kalkınma kavramı da zaman içinde önemli değişikliklere uğramıştır. Bölge temelli analizler Von

*Sorumlu yazar/Corresponding author

e-posta: selenmaden@sdu.edu.tr 
Thünen, Walter Christaller, Auguste Lösch, Alfred Weber'e kadar uzansa da bölge biliminin asıl kurucusu olarak Walter Isard anılmaktadır. Kavram ilk defa İkinci Dünya Savaşı'ndan sonraki dönemde, 1950'li yıllarda, Amerika Birleşik Devletleri'nde ortaya atılmıştır ve daha sonra çok sayıda bilim insanı bölgesel kalkınma literatürüne katkıda bulunmuştur (Tüylüoğlu ve Karakaş, 2006: 196-197). Özellikle savaşın getirdiği ekonomik yıkımları onarmak ve bölgeler arasındaki farklılıkları gidermek amacıyla bölgesel planlamalar önem kazanmaya başlamıştır. Bölgeler arasındaki ekonomik farklılıkların getirdiği demografik bozulma ve sanayinin daha güçlü olduğu kesimlerde görülen yoğun göç bu açı̆̆ı daha da büyütmüştür. 1970'lere gelindiğinde bu konu neredeyse bütün Avrupa'nın gündeminde olmakla kalmayıp kalkınma ajanslarının kurulması sürecine de hız kazandırmıştır.

Bölgesel kalkınma çalışmaları, Türkiye'de de 1960'lı yıllarda Kalkınma Planları ile başlamıştır. Bölgesel gelişmenin sağlanarak, bölgeler arasındaki farkların dengeli biçimde kapatılması için hızlı sonuçlar veren politikalar oluşturulmaya çalışılmıştır. Bunun için de bölgesel kalkınma planlarının yanı sıra, KÖY (Kalkınmada Öncelikli Yöre), teşvik ile yatırım uygulamaları, Organize Sanayi Bölgelerinin (OSB) kurulması, sosyal sorumluluk projeleri ve kırsal kalkınma projeleri gibi araçlar kullanılmıştır.

Kaynak kullanımının etkinsizliği ve kaynak yetersizliği, iklim şartlarının zorluğu, jeolojik ve jeofiziksel özellikler, pazarlara olan uzaklık ve yerleşim yapısı gibi sıkıntıların meydana getirdiği bölgeler arası gelişmişlik farklılığını minimize etmek için uygulanan geleneksel bölgesel kalkınma stratejileri dünya genelinde yetersiz kalmış, Türkiye'de ise yeterince başarıya ulaşamamıştır. Değişen piyasa koşullarına uyum sağlama ihtiyacı, rekabet anlayışının değişmesi, yaşanan hızlı teknolojik dönüşüm, geleneksel bölgeciliğin yerine yeni bir bölge yaklaşımını benimsemeyi zorunlu hale getirmiștir. Değișimler ilk olarak kalkınma ekonomisi ile başlamış, daha sonra bölgesel kalkınma stratejilerinin hedefleri, faaliyet yapısı ve araçları ile devam etmiştir. Böylece kalkınma planlarını oluşturan kurumsal yapıların da gelişmesi ve değişmesine zemin hazırlanmıştır. Öyle ki bölgesel kalkınmanın kurumsal yapısı yukarıdan aşağıya planlama anlayışından, aşağıdan yukarıya planlama anlayışına evrilmiştir. Yenidünya düzeninde, yerel dinamiklerin önemi kalkınma ve gelişme açısından daha da artmıştır.

\section{Geleneksel Bölge Anlayışı ve Kalkınma Planlarına Yansıması}

Birçok farklı tanımı yapılabilmekle birlikte, bölge kavramı iki ana akımda ele alınabilir. Bunlar; geleneksel bölge kavramı ve küreselleşmeyle şekillenen yeni bölge kavramıdır. $\mathrm{Bu}$ tanımlardan geleneksel anlayışa göre: "Bölge, yan yana gelmiş birimlerin mekânsal bütünlüğü ile oluşan, ulus devlet dışına kapalı, ulus devletin denetiminde, sınırları çizilmiş bir birimdir." Küresel anlayışa göre tanım ise: "Bölge, ilişki ağ1 ile belirlenen, mekânsal süreklilik koşulu olmayan yerellerin oluşturduğu, uluslararası ilişkilere doğrudan açılan, sınırları değişken bir birimdir" (Apan, 2004: 40).

Avrupa'da geleneksel anlayışa dayalı bölgesel kalkınma yaklaşımının -Roma Anlaşması'nın hedefleri doğrultusunda- bölgeler arasındaki farklılıkları gidermeye çalışmak amacıyla başlatıldığı bilinmektedir. Avrupa Tek Senedi'nde de bu amaç için kesin ve net araçlar belirtilmemiş olmasına karşın resmi olarak bölgesel kalkınma kavramı yürürlüğe konulmuştur. $\mathrm{Bu}$ aynı zamanda ekonomik ve sosyal uyumu sağlayabilmek amacıyla bölgesel politikaların geliştirilmesi gerekliliğinin de kabulünü ifade etmektedir (Paxton, 1992: 213). Paul Krugman, 1991 'de yayınladığ "Geography and Trade" adlı çalışmasında ilk kez Yeni Ekonomik Coğrafya kavramını kullanmış ve bu kavramı ölçek ekonomisi ve kümelenme yaklaşımlarıyla destekleyerek açıklamaya çalışmıştır. Yeni Ekonomik Coğrafya Teorisinde önceki geleneksel teorik varsayımların aksine üretim faktörlerinin hareketliliği ve taşıma maliyetlerinin varlığı ortaya konulmuştur. Yine bu teoride belirli bölgelere odaklanan kalkınma yaklaşımı ön plana çıkarken, ticari engellerin olmadığ kurgulanmıştır. Krugman, belirli bir bölgede gerçekleşen sektörel yoğunlaşmanın uzun vadede geliri artıracağını savunmaktadır (Krugman, 1991). Sonrasında ise bölgesel kalkınma kavramına uygun olarak, bölgelerin sınıflandırılması, istatistikî analizlerin yapılması, farkların belirlenerek bölgelere en uygun politikaların düzenlenmesi amacıyla Bölge Birimleri Sınıflandırması anlamına gelen NUTS Bölgeleri kurulmuştur (Güler, 2005: 147).

Türkiye'de ise Cumhuriyet'in ilk ylllarından itibaren kalkınma hamlelerine büyük önem verilmiştir. Ancak bölgesel kalkınma yaklaşımının 1960 sonrası planlı dönemle birlikte başladığı söylenebilir. Planlı dönem öncesi bazı bölgesel raporlar hazırlanmış olsa da sistemli yaklaşımların planlı dönemle ağırlık kazandığını söylemek yanlış olmayacaktır. Birinci Beş Yıllık Kalkınma Planı'nda (1963-1967), bölge planlamasının "kalkınmanın bölgeler arası dengesizlikleri önleyici bir yönde olmasını, aşırı şehirleşme ve nüfus problemlerinin çözülmesini, kamu hizmetlerinin gelir dağılışını düzeltici bir şekilde dağıtılmasını, potansiyel kaynakları olan firelerin düzenli bir şekilde gelişmesini sağlayacağı” belirtilmiştir. İkinci Kalkınma Planı'nda (1968-1972) milli plandan bağımsız olarak bölgesel anlamda başka bir plan düzenlenemeyeceği dile getirilmiş olsa da Üçüncü Kalkınma Planı (1973-1977) KÖY (Kalkınmada Öncelikli Yöreler) uygulamasını hayata geçirmesi açısından bir dönüm noktası niteliği taşımaktadır. Bölgesel Planlama açık ve net olarak Beşinci Kalkınma Planında (1985-1989) ele alınmış, bunun için DPT (Devlet Planlama Teşkilatı) görevlendirilmiştir. "Türkiye'de Yerleşme Merkezlerinin Kademeleşmesi” çalışmasıyla birlikte 16 bölgeli bir ayrım benimsenmiştir. Böylelikle ilk kez bir planda bölgesel bir ayrıma yer verilmiştir. Altıncı Kalkınma Planında her ne kadar bu 16 bölge bir kenara bırakılıp KÖY uygulamasına ağırlık verilmiş olsa da Yedinci Kalkınma Planında (1996-2000) "Bölgesel Dengelerin Sağlanması” başlığı altında, bölgesel gelişme ve il planlama ile ilgili önemli düzenlemelere yer verilmiştir (DPT, 1964). Yine bu plan çerçevesinde Avrupa Birliği müktesebatına uyum teşvikiyle beraber NUTS bölgeleri kurulmuştur. Sekizinci Kalkınma Planında (2001-2005), Avrupa Birliğine uyum süreci için çalışmalara hız kazandırılması, bölgesel kalkınma alanında da kendini göstermiştir. Teknoloji ve AR-GE gibi alanlarda teşviklerin verilmesi, eğitim sisteminin daha kaliteli bir hal alması ve yeni sanayi odaklarının oluşturulma çabaları bu planda öne çıkan bölgesel kalkınma göstergelerindendir (DPT, 2000). 
$\mathrm{Bu}$ plandan sonra bölgesel kalkınma boyut değiştirmiş ve zaman içinde de büyük değişiklikler göstermeye başlamıştır. Dokuzuncu Kalkınma Planında, teşvikler önemli oranlarda arttırılmış, bu sayede yatırım artışı ve istihdam verilerinin düzeltilmesi amaçlanmıştır. KÖY uygulamasına bağlı yerlerdeki işletmeler için bazı gelir vergisinde ve SSK prim ödemelerinde indirime gidilmiştir. Yine özellikle bu bölgelerdeki il özel idareleri ve belediyelerin, projeleri için özel ödenekten desteklenmesine devam edilmiştir (DPT, 2006).

\subsection{Geleneksel Bölgesel Kalkınma Yaklaşımları}

Bölgesel Kalkınma Politikaları, 1929 Büyük Buhran sonrasında, özellikle kalkınma iktisadının yeniden yükseldiği dönemde önem kazanmaya başlamıştır. $\mathrm{Bu}$ dönemde Keynesyen politikalar ön planda olup, kalkınma politikalarına da bu çerçevede yön verilmiştir. Bu dönemde benimsenmiş olan ulus-devlet anlayışı gereği de bu ortama zemin hazırlanmış, bölgeler, ülkelerin alt parçaları olarak görülmüştür. Bununla birlikte 1950-1960'lı yıllarda korumac1-müdahaleci iktisat politikalarına geçilmiştir. $\mathrm{Bu}$ dönemde büyüme öncelikle mikro düzeyde ele alınmış, sürdürülebilir büyümenin sağlanması için ise ülke içindeki geri kalmış bölgelerin kalkındırılması gerekliliği benimsenmiştir. Bundan dolayı da bölgelere planlı bir müdahale gerekliliği önemle vurgulanmaya başlanmıştır. $\mathrm{Bu}$ dönemdeki kalkınma yaklaşımlarını genel iki başlıkta incelemek mümkündür.

\subsubsection{Keynesyen Bölgesel Büyüme Yaklaşımı}

1929 Buhranı sonrasında özellikle önem kazanan kalkınma kavramı literatürde geniş yere sahip olmuştur. Özellikle bölge kavramı, her ne kadar iktisatçıların kullandığı bölge kavramı ile birebir uyuşmasa da, kalkınma ile beraber anılmaya başlanmış, bölgelerarasındaki uyumsuzluğu gidermek, kalkınma ve büyümenin tabanını oluşturmuştur. 1950 ve 1960 'l y yllarda ise talep yönlü iktisat politikaları benimsendiğinden Keynesyen politikalar daha da ön plana çıkmış ve özellikle kalkınma planlarının ayrılmaz parçası olmuştur. 1970'li yıllarda yaşanan petrol şoklarına kadar da bu anlayış devam etmiş, bu iki önemli olaydan sonra yaşanan stagflasyona reçete olarak iktisat politikalarında neo-liberal yaklaşımların etkisi görülmüştür (Aktakaş, 2006: 30; Kaya, 2007: 62)

Keynesyen büyüme modelinde, kalkınmanın temelinde bölgesel kalkınma gerekliliği yatmaktadır. Keynes'in analizine göre makroekonomik sorunlar (özellikle işsizlik, enflasyon ve durgunluk) yurtiçi üretimin satın alma miktarındaki dalgalanmalarla doğrudan ilişkili olmasından kaynaklanmaktadır. Ekonomide eksik istihdamdan kurtulmak için ise toplam talebin arttırılması gerekmektedir. Toplam talebin artması ise yatırımları tetikleyecek ve bu şekilde büyüme gerçekleşecektir (Göktaş: 2005: 66).

Keynesyen tabanlı birçok büyüme modeli bu dönemde ortaya çıkmıştır. Bunların en önemlilerden biri HarrodDomar Büyüme Modeli'dir. Bu model yatırım ve tasarruflar üzerine kurulu bir büyüme modelidir. İki önemli varsayım üzerine kurulmuş bu modelde, birinci varsayım, üretimin sermayeye bağlı olmasıdır. İkinci varsayım ise sermaye birikiminin gelire bağlı olmasıdır. (Taban, 2010:
23-24). Ancak Keynesyen politikada başarı, merkezi hükümetin sahip olduğu maddi güç ile doğrudan ilişkilidir. Buna bağlı olarak 1970'li dönemde krizlerden sonra yaşanan, sıkıntılı süreçte, bütçe yapıları zayıflamış ve Keynesyen temelli bölgesel kalkınma stratejileri işlemez hale gelmiştir. Özellikle bölgesel geliri yükseltmek ve istihdamı arttırmak amacı taşıyan bu politikalar verimliliği geri planda tuttuğundan dolayı sürekli kamusal desteğe ihtiyaç duyan yerel ekonomilerin oluşmasına neden olmuştur. 1973 Krizi sonrasında ise bu durum, yavaş yavaş yerini yeni politika anlayışına bırakmaya başlamıştır.

\subsubsection{Neoklasik Bölgesel Büyüme Teorisi}

Keynes'in Klasik İktisat Teorisi'ne yaptığı eleştirinin bir analizi olarak ortaya çıkan Neoklasik Büyüme Teorisi, ekonominin tam istihdama ulaşması için gerekli şartlara bağlıdır. Özellikle Solow ve Swan'ın (1956) öncülüğünde gerçekleşen bu akımın temel varsayımlarında ölçeğe göre sabit getiri ve sermaye verimliliğine göre azalan trend söz konusudur. Ayrıca yine bu varsayımlara göre nüfus oranı da sabit olarak artmaktadır. Sinırlı devlet müdahalesini benimsemiş olan bu teoriye göre, iki temel öngörü söz konusudur. Bunlardan ilki gelişmekte olan ve gelişmiş ülkelerden daha çok tasarruf eden ülkenin, daha fazla sermaye yoğun ve zengin olacağıdır. Bununla birlikte model azalan verimlerle açıklandığından, ekonomik büyümeyi etkileyen asıl unsur, nüfusta ve teknolojideki değişme olmaktadır. (Kar vd, 1998: 3)

Diğer bir öngörü ise teknolojik düzeyin her ülkede aynı olması varsayımından hareketle, gelişmiş ve gelişmekte olan ülkelerin uzun dönemde birbirini yakalayacak olmasıdır. Yakınsama Hipotezi de denilen bu hipoteze göre sermayenin getirisinin yüksek olduğu fakir ülkelere doğru bir akış olmaktadır ve sermayenin işgücünden daha hızlı arttığı bir ekonomide, teknolojinin sabit olduğu varsayıldığından, faiz hadleri düşecek, buna bağlı olarak da fakir ülkeler zengin ülkelere göre daha hızlı büyüyeceklerdir (Kibritçioğlu, 1998: 207). Ancak bu öngörüler haricinde modelin zayıf tarafları da söz konusudur. Küreselleşmeye açık ve hazır olmayan yerel ekonomilerin kırılganlığa mahkûm edilmiş olması modelin açıklama gücünü zayıflatmıştır. Bu zayıflama karşısında yükselen İçsel Büyüme Teorilerinin Neoklasik yaklaşıma getirdiği eleştiriler de Solow modelinin geçerliliğini azaltması yönünden önem arz etmektedir.

\section{Yeni Bölgeciliğe Geçiş}

Küreselleşme hareketinin özellikle 1990 sonrasında ivmelenmesi, beraberinde yerelleşme olgusunu da ön plana çıkarmıştır. Bu hareket aynı zamanda hem siyasi hem de ekonomik değişimlerin temelini oluşturmuştur. Sanayi toplumunun yerini bilgi toplumunun almaya başlaması, fordist üretimden esnek üretime geçiş aşaması ve modernizmin yerini post-modern düşünceye bırakması, bu değişimleri tetikleyen hareketler olmuştur (Tekeli, 1962: 30).

Bölgeler arası eşitsizliğin artmasına neden olan sorunlu bölgelerin, kalkınma ve ekonomik büyümeye olan negatif etkisi halen daha çözülememiş bir sorun olma özelliğini taşımaktadır. Gelir düzeyinin düşüklüğü, işsizlik oranındaki artışlar, göç, sürdürülebilir yerel rekabetin sağlanamaması 
yeni politikalara ve yaklaşımlara ihtiyaç duyulduğunun bir göstergesi olmuştur (Danson, 1999'dan akt. Erzi,2004: 7). $\mathrm{Bu}$ sorunlar, geçmişte deneyimlenmiş geleneksel yaklaşımın yerine, daha rekabetçi, yenilikçi ve önceliği yerel bölgelerin kalkınmasına ağırlık veren yeni bölgesel politikaların oluşmaya başlamasına yol açmıştır. Tüm bunların 1şığında gündeme gelen yeni yaklaşım Yeni Bölgecilik Yaklaşımı olarak tanımlanmaktadır (Erzi, 2004: 5). Yeni bölgecilik yaklaşımı, daha önceki dönemlerde uygulanmakta olan gerek Keynesyen gerekse Neoklasik yaklaşımdan daha fazlasını içeren; sosyo-ekonomik ve kurumsal çerçeveleri de dikkate alan bir anlayışla ele alınmaktadır. Bir başka ifadeyle bölgeleri başarıya götürecek faktörleri ele alan bu yaklaşım, üretim faktörlerinin hareketliliği gerçeği çerçevesinde, diğerlerinden nasıl daha üstün bir performans gösterdiği üzerinde yoğunlaşmaktadır. Yeni Bölgecilik yaklaşımını diğer geleneksel yaklaşımlardan ayıran bir diğer önemli nokta da, geleneksel yaklaşımların bölgelerin başarı performansını açıklamakta yetersiz kalması ve bölge başarısını sadece ekonomik faktörlere dayandırmasıdır (Okcu vd., 2005: 2-4). Geleneksel bölgesel kalkınma yaklaşımlarıyla yeni bölgecilik yaklaşımları arasındaki 3 temel fark bulunmaktadır: (Dulupçu vd, 2010: 242). İlk olarak, geleneksel bölgesel kalkınma anlayışının temel hedefi bölgesel gelişme iken bu anlayış yeni bölgecilikte yerini bölgesel yeniliğe bırakmaktadır. İkinci olarak, geleneksel bölgesel kalkınmada temel kaynak olarak "bölgeler arası yeniden dağıtım" kullanılırken yeni bölgecilikte yerel ve bölgesel kaynakların harekete geçirilmesine odaklanılmaktadır. Son olarak da, yeni bölgeciliğin bilgiye ve bilgi üretimine yönelik kaynaklara ve yenilikçiliğe vurgusu belirgin bir şekilde kendini göstermektedir.

\subsection{Yeni Bölgecilik Yaklaşımları}

Yeni bölgecilik yaklaşımını oluşturan iki temel yaklaşım söz konusudur. Bunlar; içsel büyüme yaklaşımı ve cazibe merkezi yaklaşımıdır.

\subsection{1. İçsel Büyüme Yaklaşımı}

Neoklasik iktisat görüşünün temelinde yer alan Solow'un 1956 yllında ortaya koyduğu dışsal büyüme teorisinin aksine 1980'li y1llardan itibaren büyümeyi içselleştiren farklı bir sistem benlik kazanmaya başlamıştır. İçsel Büyüme yaklaşımına göre fiziki sermaye haricindeki diğer bileşenlerde, eğer ki birikim artarsa, bu durum faktör gelirlerinin de artacağını savunmaktadır. Diğer bir adı olumlu dişsal etkiler olan bu sava göre bilginin yaygınlaştırılması veya kamu alt yapı inşaatı gibi faaliyetlerin sonucu olarak ortaya çıkan etkiler, sermayenin marjinal verimliliğindeki düşüşe karşı olabilirse içsel olarak kabul edilmektedir (Göktürk, 2006: 2). Neoklasik ve Keynesyen politikaların değerini kaybetmeye başladığ 1980'lerde bölgesel kalkınmaya yönelik olarak içsel dinamiklere vurgu yapan çalışmalar ve görüşler yankı bulmaya başlamıştır.

Başlıca savunucuları; P. M. Romer, R. J. Barro, R. E. Lucas ve G. Mankiw olan İçsel Büyüme Teorileri, teknolojik ilerlemeye olduğu kadar, eğitim, AR-GE ve beşeri sermaye gibi faktörlere de öncelik verilmesini savunur. İçsel büyüme modellerine yönelik yapılan çalışmalarda öncü isimler Romer ve Lucas olmuştur. Lucas büyümenin asıl aktörü olarak beşeri sermayeyi kabul etmektedir. (Lucas, 1988: 17). Romer'in teorisine göre ise kapalı bir ekonomiye sahip az gelişmiş ülkelerde büyümenin sağlanabilmesi için beşeri sermayenin arttırılması gerekmektedir. Romer'in teorisine göre, bir ekonomi ne kadar fazla beşeri sermaye stokuna sahip ise o kadar hızlı büyümektedir (Romer, 1990: 99). Arrow büyümeyi yaparak öğrenmeye dayandırmıştır. Arrow'a göre öğrenme zaman içinde deneyimlenerek kazanılmaktadır ve bir problemin çözümü olarak kendini göstermektedir (Arrow, 1962: 155). Mankiw ise daha önce Solow tarafından ortaya atılan büyüme modeline beşeri sermaye değişkenini ekleyerek modeli beşeri sermaye yönünden açıklamaya çalışmıştır. İçsel büyüme teorisinin ise içsel büyüme olarak adlandırılmasının temel nedeni ekonomik büyümenin içsel güçlere bağlı olduğunu kabul etmesidir ve Neoklasik yaklaşımın yakınsama hipotezinin aksine kabul ettikleri kavram 1raksamadır (Doğan, 2010: 45).

İçsel büyüme yaklaşımına göre bölge, içinde kullanılmayan değerli, birçok kaynağı bulunan ekonomik bir sistemin en alt kaynağıdır. Ekonomik büyümeye ve kalkınmaya öncülük eden ise öncelikle bölgesel anlamda değerlendirilmesi gereken bu kaynaklardır. Bundan dolayı ortaya çıkan bu yeni paradigmaya göre, bölge yapısının güçlendirilmesi, yeni iş kültürünün oturtulması ve buna bağlı olarak ilgili bölgeye yatırımcı çekilmesi, beşeri sermaye, sistem kalitesi, geliştirilebilir networkler ve öğrenme stratejileri gibi kavramlar ön plana çıkmıştır (Ertugal, 2005: 3). Bu kapsamda değerlendirildiğinde İçsel büyüme yaklaşımlarının Bölgesel Kalkınma Ajansları'nın kurulmasına da öncülük ettiği söylenebilir. Dünya'da ilk kez 1950'li yıllardan itibaren kurulan kalkınma ajanslarının öncelikli amacı, merkezi hükümetin hazırladığı kalkınma planlarına bilgi temin etmek, bu planların uygulanabilirliğini kontrol etmekti. Ancak 1980'lerde artan küreselleşme hareketleri sonucunda artan yerel rekabet ile birlikte yerel aktörlerin bölgesel kalkınma stratejilerine aktif olarak katılmasını teşvik etmek amacıyla görevlendirilmişlerdir. Avusturya, Belçika, İrlanda ve Fransa kalkınma ajansları ile ilk kez 1950'li yıllarda tanışırken, Almanya, Hollanda, İngiltere ve İtalya 1960'larda, Yunanistan, İspanya, Finlandiya ve Danimarka ise 1980'lerde tanışmıştır (Özen, 2005: 5).

\subsubsection{Cazibe Merkezleri Yaklaşımı}

Cazibe Merkezi Yaklaşımı 1960’lı yıllarda gündeme gelmiş, Kalkınma Kutupları Teorisi ile paralel bir yapı göstermiştir. $\mathrm{Bu}$ teori, Fransız ekonomist François Perroux'un 1940'lı yıllarda geliştirdiği bir teori olup, ekonomik kalkınmanın bir ülkenin tüm bölgelerinde aynı anda başlamadığını savunmaktadır. Perroux'a göre ekonomik kalkınma, uygun koşullara sahip belli bölgelerde yoğunlaşmaya başlar ve belli bir yoğunluğa ulaştıktan sonra ekonominin tümüne yayılır (Dinler, 2012: 272). Kalkınmanın belli bir bölgede başlamış olması bir tesadüf değil kalkınmanın ön koşulu olarak görülmektedir. Dolayısıyla kalkınmanın belirli sektör ve belirli bölgelerde başlamış olması, tesadüfî bir gelişmenin ötesinde ekonomik kalkınmanın bir koşulu olarak görülmektedir. Kalkınma kutupları, bu özelliğiyle dengesiz kalkınma teorileri içinde 
yer almaktadır. Yine bu teoriye göre, devlet, bölgesel yapıyı dönüştürmek için belirlemiş olduğu cazibe merkezi adı verilen kentlere kamu yatırımlarını yoğun bir şekilde gerçekleştirmektedir. Bu amaç doğrultusunda aynı zamanda kamu yatırımlarının yaratacağı bu yı ğılma ekonomisinin bölgenin tamamı için yaratacağı yeni iş imkânları, üretim kapasitesinin artması gibi dışsallıklar sayesinde bölgesel ölçekte bir refah artışı sağlanması hedeflenmektedir. Kalkınma Kutupları Teorisi, yerleşim birimlerinin çoğunda kullanılan bir gelişme modelidir. Teşvik ve sübvansiyonlar sonucunda bölgede refah artışı ve büyüme beklenmektedir. Modelin alt yapısındaki aktörleri ise girişimcilerdir (DPT, 2000).

Cazibe Merkezleri Yaklaşımına temel oluşturan bir başka teori Birikimli Nedensellik Teorisi'dir. İsveçli iktisatçı Myrdal tarafından ortaya atılan bu teoriye göre gelişmişlik farkları fazla olan iki ülkenin serbest ticareti söz konusu olursa, hem bu iki ülke arasında ekonomik entegresyon sağlanamaz hem de büyük ülke istihdam koşulları nedeniyle emek göçü alır. Bunun bir diğer nedeni ise küçük ülkenin sanayisinin, gelişmiş ülkenin sanayisi ile rekabet gücünün olmamasından kaynaklanmaktadır. Dengesiz büyüme teorilerinden olan bu teoriye göre bu gibi farklılıkları önlemek için hükümetler serbest piyasa mekanizmasının işleyişine müdahale ederek bölgesel kalkınma planları uygularlar. Dengesiz kalkınma yaklaşımına katkı yapan bir diğer araştırmacı olan Hirschman (1959) 'a göre, sektörler arası bağlılık katsayısı en yüksek olan sektöre öncelik verilmelidir ve bu şekilde diğer sektörler etkilenmelidir. Diğer bir deyişle Hirschman'a göre iç piyasanın sınırlı olması nedeniyle, az gelişmiş ülkelerde çok sayıda sektöre eş zamanlı yatırım yapılması mümkün olmadığından ekonomide en çok gelişme sağlayabilecek sektörlere yatırım yapılması gereklidir. İlk olarak bu sektörlere yatırım yapıldığında ekonomide etkinlik sağlanabilir ve tüm ekonomi hızla gelişebilir. Hirschman'a göre yatırım yapılacak bu sektör seçilirken başka sektörleri tamamlayıcı nitelik taşımasına dikkat edilmelidir (Dinler, 2001: 407).

\subsection{Dünya'da Yeni Bölgecilik İçin Yapılan Çalışmalara Genel Bir Bakış ve Türkiye'de Yeni Bölgecilik Çalışmaları}

Yeni Bölgeselcilik kavramı, yerel kaynakların tam anlamiyla harekete geçirilebilmesi amaciyla çözüm önerileri sunmaktadır. Bunun sağlanması için ise girişimci kentler, öğrenen bölgeler, Ar-ge faaliyetleri, yenilikçilik ve ağ tabanlı yönetişim gibi kavramlar gündemde yer almaya başlamıştır (Erkut ve Gönül, 2010: 381). Bu yaklaşımda, bölgelerin uluslararası alandaki rekabet çabalarının yalnızca piyasaya dayandırılmasından dolayı ortaya çıkan aksaklıklar gün yüzüne çıkarılarak, devletin rolü tekrar değerlendirilmeye alınmıştır. Buna göre devletin rolü ise 1950-1960'ların bölgesel kalkınma yaklaşımlarından farklı olmuştur (Çakmak ve Erden, 2004: 83). Diğer bir deyişle, devlet güdümünden tamamen bağımsız bir model yerine, bölgesel ve yerel girişimleri dikkate alan bir kalkınma anlayışı benimsenmiştir. Yeni Bölgeselcilik Yaklaşımı, küresel anlamda, devletçi stratejilere tepki niteliği gösteren Neoliberalizm yaklaşımının bir uzantısı olarak kendini göstermiştir. Öyle ki Neoliberal politikalara göre ülkeler arasındaki mal ve hizmetler ile para ve sermaye hareketleri üzerindeki devlet etkisi kaldırılmalıdır. Buradaki önemli husus, devletin yok sayılması değil piyasayı daha etkin bir hale getirecek yönetişim mekanizmasının kurulması varsayımıdır. $\mathrm{Bu}$ yüzden de devlet, küresel politikaların belirlenmesinde ve bu politikaların uygulanmasında baş aktördür (Şimşek, 2017: 181).

Küresel kalkınma bağlamında bu gelişmelerle beraber minimal devlet anlayışı ortaya çıkmış ve bu durum yeni bölgeselcilik yaklaşımına zemin hazırlamıştır. Yeni Bölgeselcilik Yaklaşımı, dünya genelinde Washington Uzlaşması ile beraber önem kazanmaya başlamış, "eksiklerinin" tamamlanarak geliştirilen İkinci Washington Uzlaşması ile birlikte de devam etmiştir. Washington Uzlaşması kavramı ilk olarak John Williamson tarafından 1989 yılında kullanılmış olup IMF ve Dünya Bankası gibi uluslararası kuruluşların düşüncelerini yansıtmaktadır. 1980'li yılların başlarından itibaren yapısal uyum programları dâhilinde IMF ve Dünya Bankası'nın üyelerine uygulattırdığı politikalara verilen isimdir (Williamson, 2004, akt. Erakbaş,2008). Bu uzlaşılarda yer alan maddeler Tablo1'de gösterilmektedir.

Tablo 1. Neo Liberal İktisat Politikaları

\section{Birinci Washington Uzlaşması}

\section{İkinci Washington Uzlaşması}

Yolsuzluğa karşı önlemler Esnek işgücü piyasaları DTÖ anlaşmaları Finansal kurallar ve standartlar İhtiyatlı sermaye hesapları açılması

Aracı olmayan döviz kur rejimi

Bağımsız merkez bankası

Enflasyon hedeflemesi

Sosyal güvenlik ağları
Mülkiyet haklarının güvence

altına alınması

\section{Kaynak: Rodrik, 2006: 978}

Yeni bölgeselcilik yaklaşımının temelini oluşturan yeni kalkınma yaklaşımında, büyümenin nasıl arttırılabileceği sorusu yerini yaşam standartlarının nasıl yükseltilebileceği konusuna bırakmıştır. İlk olarak ekonomik kalkınmanın doğal çevreye etkisi şeklinde tartışılan bu konu zamanla yaşam kalitesini de kapsayacak şekilde tekrar ele alınmıştır. Bu değişim de yeni politikalara geçilmesine neden olmuştur (Pike, Rodrigez ve Tomaney 2006; Pike, Rodrigez ve Tomaney, 2011).

AB bölgesel politikalarına da yansıyan yeni kalkınma stratejileri üçüncü dönemi, 18 Şubat 2004'te Avrupa Konseyi tarafindan 2007-2013 dönemi için kabul edilen "Yeni Uyum Ortaklığı: Yakınsama, Rekabetçilik ve İşbirliği" raporu ile başlamıştır. Bu dönem günümüz bilgi ekonomisinde bölgesel gelişmeyi sağlayacak bileşenlerin esas alındığı dönemdir. Yeni politikalar, üç temel amaç çerçevesinde şekillenmiştir. Bunlardan ilki; özellikle az gelişmiş bölgelerde istihdam ve büyüme koşullarının iyileştirilmesidir. $\mathrm{Bu}$ amaca ulaşılabilmesi için beşeri ve fiziksel sermayeye yatırımın yanı sıra, bilgi toplumunun 
geliştirilebilmesi için yeniliklerin yapılması ve ekonomik ve sosyal değişimin teşvik ile desteklenmesi gerekmektedir. $\mathrm{Bu}$ politikaların ikinci önceliği ise, rekabet edebilirlik ve istihdam ile ilgilidir. $\mathrm{Bu}$ önceliğin amacı ekonomik değișimin sağlanmasıdır, yani diğer bir deyişle yatırımcı için çekiciliğin arttırılarak yeni istihdam alanları yaratacak yatırımların yapılmasıdır. Yeni dönemin üçüncü önceliği ise Avrupa bölgesel ortaklığıdır. Öncelikli amaç Birliğin dengeli ve uyumlu bir süreçte kalkınmasıdır. Bu amaç doğrultusunda, bölgelerarasında sınır ötesi, uluslararası ve ulusal düzeydeki işbirliğinin geliştirilmesine yönelik projeler geliştirilecektir. (Kumral, 2008: 9) Böylece bilgiye dayalı artan getiri söz konusu olacaktır. Bu amaçlar doğrultusunda $\mathrm{AB}$ uyum süreci içinde, mikrodan makro düzeye doğru kalkınma stratejileri geliştirilmekte ve yeni bölgeselcilik zemininde yükselmeye çalışılmaktadır. Bunun için akılll uzmanlaşma, rekabet ve inovasyon stratejileri (RIS), öğrenen bölgeler ve kümelenme gibi kavramlar da önem kazanmıştır.

Akıllı Uzmanlaşma kavramı ilk olarak Dominique Foray ve Bartvan Ark tarafından ortaya atılmış olup, "Knowledge for Growth" uzman grubu tarafindan 2006-2009 yıllarında geliştirilmeye başlanmıştır (Foray, 2009: 19 akt: Kutgi ve Maden, 2017: 3). Son yıllarda ise AB ülkeleri ekonomik kalkınma ve büyüme stratejilerini akıllı uzmanlaşmayı temel alarak oluşturmaktadır ve 2014-2020 yıllarını kapsayan üçüncü nesil inovasyon stratejileri de yine akıllı uzmanlaşmaya bağlı olarak geliştirilmektedir. Avrupa 2020 Stratejisinin de temeli olarak görülen bu kavramı akıllı, sürdürülebilir ve kapsayıcı büyüme oluşturmaktadır. Geleneksel yaklaşımlardan iki yönüyle ayrılan bu yaklaşımın ilk özelliği yenilik sistemi, diğer özelliği ise bu stratejinin hangi yöntemlerle işlendiğidir. Bölgenin evrimini, miras alınan yapılarını, adaptasyonunu ve bölgede medyana gelen değişiklikleri bir bütün olarak ele almasını ifade eden yenilik sistemi, bilgi yoğun alanların belirlenmesi yöntemiyle dinamik olarak uygulamalara konu olmasını önermektedir. Akademik ve araştırma işbirliği ile etkin rol oynayan bölge oyuncuları, bilginin en iyi şekilde işlenmesi, mevcut yerel firsatların belirlenerek, teknoloji ve pazar alanlarının oluşturulması ve bununla birlikte de katalizör görevi görerek ekonomide yeniliğe olanak sağlamaları açısından önem teşkil etmektedir (McCann ve Ortega-Argiles, 2011: 2). Bu yanıyla değerlendirildiğinde akıllı uzmanlaşma sadece teknoloji lideri bölgelerin değil, diğer bölgelerin de mukayeseli üstünlükte etkin olduğu faaliyetlere yoğunlaşarak avantaj sağlayabilmesine vurgu yapmaktadır. Akıllı uzmanlaşma stratejinin temel unsurlarının başında bölgenin kendini bilmesi gelmektedir. Diğer bir deyişle bölgenin en iyi neyi yapabileceğini keşfetmesi büyük önem taşımaktadır. Daha sonraki süreçte ise uzmanlaşmanın hangi seviyede yapılacağı önem arz etmektedir. Eğer söz konusu uzmanlaşmanın seviyesi çok yüksek tutulursa, uzmanlaşma tek bir sektöre yönelik olarak dönüşüm gösterir ve bu şekilde geleneksel politikalarla paralel seviyede bir politikaya dönüşür. Akı1lı uzmanlaşmada asıl önemli olan sektörün tamamında değil bazı faaliyetlerde uzmanlaşmaya gidilmesidir. Öncelik verilmesi gereken bu faaliyetler ise bölgenin mevcut faaliyetlerini destekleyici yenilikçi potansiyele sahip olan faaliyetlerdir. Akıllı uzmanlaşma ile ilgili temel unsurlardan bir diğeri uzmanlaşmış çeşitliliğe izin veren bir yenilik sisteminde ortaya çıkabilecek yeni faaliyetlerin keşiflerine izin veren bir strateji olmasıdır. Seçilmiş bölgesel veya sektörel alanlardaki uzmanlaşma zaman içinde çeşitliliğe dönüşerek yüksek oranda avantaj sağlayacaktır. Tüm bunlarla beraber akıllı uzmanlaşma stratejilerinin hedeflerinin de ölçülebilir olması önem arz etmektedir. Başarı ve başarısızlığın doğru olarak belirlenebilmesi için geri bildirimin sağlıklı olması gerekliliğine vurgu yapmaktadır (Kumral, 2015: 8-12).

Bilgiye dayalı ekonomi ve bilgi stratejilerinin öneminin artış gösterdiği bu süreçte inovasyon kavramı da kendi benliğinden daha büyük anlamlar kazanmaya başlamıştır. Yenilikçilik anlamıyla hem bir süreç hem de bir sonuca karşıllk gelen inovasyon, bölgelerin gelişimi ve rekabeti, buna bağlı olarak ise ülkelerin kalkınma ve büyümesini temsil eder hale gelmiştir. Özellikle kalkınma planlarında da fazlasıyla üstünde durulan bu kavram, giderek politika halini almıştır.

Bölgesel inovasyon stratejisi bölgelerin yenilikçiliğini arttırma noktasında önemli bir yere sahip olmuştur. Bu strateji; Avrupa Yenilikçi Bölgeler Ağı (IRE), Bölgesel İnovasyon Stratejileri (RIS) ve İnovasyon Aktarım Merkezleri (IRC) gibi ana karakterlerden oluşmaktadır. Bunlardan, Avrupa Komisyonu tarafindan da desteklenen IRE (Avrupa Yenilikçi Bölgeler Ağı) , bölgelerarası işbirliğinin sağlanması, yenilikçilik politikalarının geliştirilmesi ve uygulanması ve bu konuda çalışan diğer bölgelerin deneyimlerini paylaşmak amaciyla kurulmuştur. Bir diğer ana karakter olan IRC (İnovasyon Aktarım Merkezleri) ise Avrupa genelinde kurulmuştur ve temel amacı uluslararası teknoloji transferine destek sağlamaktır (Gök, 2006: 3-4). Türkiye'de de uygulama alanı bulan RIS, bölgelerin yenilikçiliklerini arttırmaları adına yeni stratejiler üretilmesi veya mevcut altyapının inovasyon politikaları ile doğru şekilde kullanılmasının sağlanması için yararlanılan bir politikadır. Dengeli kalkınma stratejilerinden biri olan RIS, 1994 yılında AB'de benimsenmiş ve iki amaca yönelik olarak uygulanmaya başlamıştır. Bu amaçlardan birincisi, kamuda yoğunlaşan Ar-Ge sürecinin özel kesime aktarılabilmesi, ikincisi ise Amerika ve Japonya ile AB'nin arasındaki teknoloji açı̆̆ının kapatılmasıdır.

Birçok AB üyesi ülke RIS kapsamında önemli başarılar göstermiş olsa da 2012 y1lına gelindiğinde kamu katılımındaki yetersizlikten dolayı birçok sorunla karşılaşılmıştır. $\mathrm{Bu}$ durum da RIS3 adı verilen yeni bir modellemenin ortaya çıkmasına ortam yaratmıştır. 2012 yılında gündeme gelen akıllı uzmanlaşma (RIS3) stratejisinin bünyesinde yer alan öğeler aşağıdaki gibidir:

1. Ulusal ve bölgesel anlamda öncelikli olan yatırımların desteklenmesi,

\section{Bölgesel bağlamda üstünlüklerin öne çıkarılması,}

3. Teknoloji yanında uygulamaya yönelik yeniliklerin desteklenmesi,

\section{Paydaş katılımının sağlanması,}

5. Kanıta dayalı girişimciliğin özendirilmesi yanında izleme ve değerlendirme süreçlerinin güçlendirilmesi.

RIS ve RIS 3 süreçlerinin arasında farklılıklar bulunmaktadır. RIS yaklaşımı gelişmekte olan sektörlerin 
öne çıkarılmasını, başarısızlık yaşanması durumunda temel nedenin firmanın veya bölgenin uygun aktif yapıya sahip olmaması olarak açıklamaktadır. RIS3 stratejisi ise, içinde bulunulan kümelenme yapısından hareketle, aktiflerin tanımlanmasını, güçlü olduğunuz yönlerin yüksek katma değer alanlarına yoğunlaştırılmasını hedeflemektedir. Bahsi geçen bu dinamikler Avrupa Birliği'nin 2020 Hedefleri olarak algilanmaktadır.

Türkiye'de ise Onuncu Kalkınma Planı'nda bölgesel alanda yenilikçilik ön planda tutularak yüksek katma değerli küme oluşumlarının teşvik edileceği, bu kümelerdeki işletmeler arası işbirliklerinin artırılacağı, kümelerin uluslararası piyasalarla bütünleşmelerinin güçlendirileceği ve desteklerde merkezi ve bölgesel düzey uyumunun gözetileceği ifade edilmektedir. RIS stratejisi ise il olarak Mersin Bölgesinde uygulanma firsatı bulmuştur. (CKA, 2017) Türkiye'de gelişmeler özellikle tam anlamıyla Onuncu Kalkınma Planı ile kendini göstermeye başlamıştır. Onuncu Kalkınma Planının (2014-2018) hedeflerinde bölgesel kalkınma planlarının önemi, daha fazla çalışma ve uygulama gerektirdiği, uluslararası alandaki rekabet göz önüne alındığında, hem milli planların hem de bölgesel planların yeni gelişmelere uyarlanması açısından farklılaştırılmaya ve geliştirilmeye gidilmek istenmesi yer almaktadır. Bölgeler arası farklılıkların giderilmesinde daha yenilikçi çalışmalar hedeflemiş olan bu planda şehirlerin düzensiz ve dengesiz büyümesi, barınma, altyapı, güvenlik ve trafik gibi sorunların üzerinde durularak, bu sorunların önemi bir kez daha vurgulanmıştır. Özellikle kentsel dönüşüm çabalarının arttırıldığı bu planda kentlerin daha yaşanabilir yerler olması hedeflenmiştir. Yine kentsel dönüşüm ve sanayi dönüşümü arasındaki ilişki ilk defa bu planda dile getirilmiştir. (DPT, 2013: 65).

\section{Sonuç}

Ülkemizde 2000'li yıllara kadar olan süre zarfında kalkınma politikaların merkeze yönelik düzenlenmesi, bölgesel anlamda yerel aktörleri arka planda bırakmıştır. İlk kalkınma planlarından itibaren ele alınan bölgeler arası gelişmişlik farklarının azaltılması hedefi, kalkınmada öncelikli yöreler uygulaması, devlet yardımları, kırsal kalkınma projeleri veya bu amaçla kurulan kalkınma ajansları hedeflenen sonuçları istenilen düzeyde verememiştir. Durumun böyle bir hal alması da kaynak yetersizliği ve bölgesel örgütlenmede eksikliği gündeme taşımıştır.

Kalkınma planlarındaki bölgesel örgütlenme eksiliğinin giderilmesine yönelik yeni hedefler, yeni stratejileri de beraberinde getirmiştir. Dünya genelinde Washington Uzlaşması ile gündeme gelen Yeni Bölgeselcilik Yaklaşımı Neoliberalizmin getirdiği minimal devlet anlayışının bir uzantısı olarak ortaya çıkmış ve zamanla yayılmaya başlamıştır. Sonrasında Avrupa Yenilikçi Bölgeler A ğı (IRE), Bölgesel İnovasyon Stratejileri (RIS) ve İnovasyon Aktarım Merkezleri (IRC) gibi ana karakterlerden oluşan bölgesel inovasyon stratejileri de bölgelerin yenilik anlayışının geliştirilmesi için önemli bir paya sahip olmuştur. Türkiye'nin ise bölgesel kalkınma politikalarında değişikliklere gitmesinin en büyük nedenlerinden biri $\mathrm{AB}$ uyum sürecinde bulunması olmuştur. Bu kapsamda ilk olarak Dokuzuncu Kalkınma Planı'nda bölgesel kalkınma politikalarının geliştirilmesi yoluna gidilmiştir. Bu hedef kapsamında girişimci kentler, öğrenen bölgeler, Ar-ge faaliyetleri, yenilikçilik ve ağ tabanlı yönetişim gibi kavramlar üzerinde yoğun bir çalışma başlatılmıştır. Yeni bölgeselcilik yaklaşımının da temelini oluşturan kalkınma yaklaşımında, büyümenin nasıl arttırılacağından çok yaşam standartlarının nasıl yükseltilebileceği konusu üzerinde durulmuş, öğrenen bilgi toplumu ön plana çıkmıştır. Devletin doğrudan dahil olması durumu ve sağladığı yardımların yerini yaşam kalitesi ve işgücünün arttırılması, güçlü yönlerin ön plana çıkarılması gibi amaçlar için yapılan yatırımlar almaya başlamıştır. Diğer bir deyişle mekânın önemini arttırmak amacıyla yenilikçilik, öğrenme, ağ ilişkileri kurma gibi unsurlar ön plana alınmıştır. Rekabet edebilirlik ve sürekli öğrenme, buna bağlı olarak da dengeli kalkınma hedefi doğrultusunda yerel kalkınma araçları çeşitlendirilmiştir.

\section{Kaynakça}

Aktakaş, B.G (2006).Bölgesel Yerel Kalkınma, Bölgesel Gelişme İçin Bir Model, Yayınlanmamış Yüksek Lisans Tezi, Çukurova Üniversitesi Sosyal Bilimler Enstitüsü, Adana, s.30

Apan, A. (2004). Bölge Kavramı ve Bölgesel Kalkınma Ajansları, Çağdaş Yerel Yönetimler Dergisi, Cilt 13, Say14, Ekim, 39-58

Arrow, K. J.(1962). The Economic İmplications of Learning by Doing. Review of Economic Studies, 29, p. 155

CKA, http://www.cka.org.tr/dosyalar/RIS_Mersin_ArGe_ve_Inovasyon_MDA.pdf, Ulaşım Tarihi: 12.01. 2018$)$

Çakmak, Hatice K. \& Erden, L. (2004). Yeni Bölgesel Kalkınma Yaklaşımları ve Kamu Destekleme Politikalar1: Türkiye'den Bölgesel Panel Veri Setiyle Ampirik Bir Analiz. Gazi Üniversitesi İktisadi ve İdari Bilimler Fakültesi Dergisi, 6(3), s.83

Danson, M.,Whittam, G., (1999). Regional Governance, Institutions and Development, Regional Research Institute, West Virginia University

Dinler, Z. (2001).Bölgesel İktisat, Bursa: Ekin Kitabevi Yayınları, s.407

Dinler, Z. (2010).Cumhuriyetimizin Kuruluşundan Günümüze İzlenen Bölgesel Kalkınma Politikaları ve Kalkınma Ajansları, Türkiye'de Bölgesel Kalkınmanın Yeni Örgütleri: Kalkınma Ajansları, ed. Birol Akgül \& Nisfet Uzay. Bursa: Ekin Yayınevi, s.53

DPT (2000). Sekizinci Beş Yıllık Kalkınma Programı, Bölgesel Gelişme Özel İhtisas Komisyonu, Ankara.

DPT, IX Beş Yıllık Kalkınma Planı (2007-2013), Ankara, 2006, s.46

DPT, İkinci Beş Yıllık Kalkınma Plânı (1968-1972), Ankara, 1968, s. 263-268

DPT, V. Beş Yıllık Kalkınma Plânı (1985-1989), Ankara, Yayın No: 1974, s.161,163.

DPT, VIII. Beş Yıllık Kalkınma Planı (2001-2005), Ankara 2000, s.63.

DPT, X Beş Yıllık Kalkınma Planı (2014-2018), Ankara, 2013, s.65

Dulupçu, M. A., Sungur, O. Keskin, H. (2010). Bölgesel Kalkınmada Yeni Yaklaşımlar ve Türkiye'de Kalkınma 
Planlarına Yansımaları: Kalkınma Planlarının Yeni Teoriler Açısından Değerlendirilmesi. 6. Ulusal Coğrafya Sempozyumu Ankara Üniversitesi Türkiye Coğrafyası Araştırma ve Uygulama Merkezi, Ankara

Erakbaş, M. http://blog.erakbas.com/washington-uzlasmasive-imf-turkiye-iliskileri/, Ulaşım Tarihi: 10.01.2018

Erkut, G. ve Gönül, D. (2010).Türkiye'de ve Dünya'da Bölge Planlama Politikalarının Evrimi ve İzmir Kalkinma Ajansi Deneyiminden Yansıyanlar./Türkiye'de Bölgesel KalkınmanınYeni Örgütleri: Kalkınma Ajansları, ed. Birol Akgül \&Nısfet Uzay. Bursa: Ekin Yayınevi, s.381

Ertugal, E. (2005). Europeanisation of Regional Policy and Regional Governance: The Case of Turkey, European Political Economy Review, s.3.

Erzi, G. (2004).Türkiye'nin Bölgesel Gelişim Süreci ve Yeni Bölgecilik, Yayınlanmış Yüksek Lisans Tezi, İstanbul Teknik Üniversitesi Fen Bilimleri Enstitüsü, İstanbul, s. 15

Foray., David P.A ve Hall., B.(2009). Smart Specialisationthe Concept, Knowledge Econimists Policy Brief n:9. 3. Akt: Kutgi, Demet ve Işık Maden, Selen (2018), Bölgesel Yenilik Sistemlerinde Yeni Bir Yaklaşım: Akıllı Uzmanlaşma Stratejisi ve Teorik Temelleri, Dumlupınar sosyal Bilimler Dergisi

Gök, T. (2009). RIS Mersin Projesi Üzerine Bir Özet Değerlendirme, TMMOB Şehir Plancıları Odası Dergisi, 47, s. 3

Göktaş, Ö. (2005). Türkiye Ekonomisinde Büyüme İle İşsizlik Oranları Arasındaki Nedensellik İlişkisi, İstanbul Üniversitesi İktisat Fakültesi Ekonometri ve İstatistik Dergisi, Sayı 2, s. 66.

Göktürk, A. (2006).Bölgesel Dengesizliğe KüreselleşmeYerelleşme Penceresinden Bir Bakış, "Bölgesel Kalkınma Politikalar ve Yeni Dinamikler", Derin Yayınları, İstanbul, s. 24.

Güler Birgül A. vd.(2005). Bölge Kalkınma Ajansları Nedir? Ne Değildir?, Paragraf Yayınevi, Ankara, s. 147,148

Hirschman, A. O (1959). TheStrategy of Economic Development, New Haven

http://www.cka.org.tr/dosyalar/RIS_Mersin_ArGe_ve_Inovasyon_MDA.pdf,(Ulaşım Tarihi: $12.01 . \overline{2} 018, \mathrm{~s} .8-13)$

Ildırar, M. (2004). Bölgesel Kalkınma ve Gelişme Stratejileri, Nobel YayınDağıtım, Ekim, Ankara

Kar, M. ve Ağır, H. (1998).Türkiye ede Beşeri Sermaye Ve Ekonomik Büyüme: Nedensellik Testi (Neo-Klasik Büyüme Teorisi), KSÜ Yayınları, s.3.

Kaya, A. ve Bafoil, F. (2009). Bölgesel Kalkınma ve Avrupa Birliği: Karabük, Valenciennes ve Katowice Karşılaştırmalı Analizi, İstanbul Bilgi Üniversitesi Yayınları 280, İstanbul, 2009, s.28

Kaya, K. (2007). Bölgesel Kalkınmada Yeni Bir Model; Kalkınma Ajansları ve Türkiye'de Uygulanabilirliği, Yayımlanmamış Yüksek Lisans Tezi, Atılım Üniversitesi, Sosyal Bilimler Enstitüsü, Ankara

Kibritçioğlu, A. (1998). İktisadi Büyümenin Belirleyicileri ve Yeni Büyüme Modellerinde Beşeri Sermayenin Yeri, Ankara Üniversitesi Siyasal Bilgiler Fakültesi Dergisi, Ocak-Aralık Cilt 53, Ankara, ss. 207-230.

Krugman, P. (1991). Geography and Trade. Cambridge: MIT Press
Kumral, N. (2008).Bölgesel Rekabet Gücünü Artırmaya Yönelik Politikalar, https://www.researchgate.net/publication/5012185, pdf. 6-9, Ulaşım Tarihi: 12.12.2017

Kumral, N. ve Güçlü, M. (2015).Akıllı Uzmanlaşmaya Yönelik Bölgesel Araştırma ve Yenilik Stratejisi Hazırlama Kilavuzu, http://www.iibf.ege.edu.tr/economics/papers/wp1501.pdf, Ulaşım Tarihi: 12.01.2018, s.8-12

Lucas, R. E. (1988). On the Mechanics of Economic Development. Journal of Monetary Economics, p.17

Mccann, P., Ortega-Argiles, R. (2011), Smart Specialisation, Regionaland Applications to EU Cohosion Policy, Economic Geography Working Paper 2011.

Okcu, M., Dulupçu, M.A. ve Gül, H. (2005).“Türkiyee de bölgeselleşme mi bölgeselcilik mi? ayrımlar ve açılımlar”, KEAS'05: Kentsel Ekonomik Araştırmalar Sempozyumu-II, 13-16 Haziran, Denizli.

Özen, P. (2005). Bölge kalkınma Ajansları, TEPAV, http://www.tepav.org.tr/upload/files/1271245092r8246. Bolgesel_Kalkinma_Ajanslari.pdf, s.5, Ulaşım Tarihi: 09.12.2017

Paxton J. (19929. , European Communities, International Organizations Series Selective, Critical, Annotated Bibliographies, Volume 1, Clio Press, United States of America, s.213

Pike, A.,Rodrigez, P. A. And Tomaney, J. (2011). Handbook of Local and Regional Development, Routledge.

Rodrik, D. (2006). Goodbye Washington Consensus, Hello Washington Confusion? A Review of the World Bank's Economic Growth in the 1990s: Learning From A Decade of Reform, Journal of Economic Literature, XLIV (December), p.977

Romer, P. M. (1990).Endogenous Technological Change. Journal of Political Economy, p.99

Şimşek, O. (2017). Washington ve Post-Washington Uzlaşmaları Çerçevesinde Neoliberalizmde Devletin Rolü, Karatahta İş Yazıları Dergisi Sayı: 7/ Nisan 2017, S. 181

Taban, S. (2010). İçsel Büyüme Modelleri ve Türkiye. Bursa: Ekin Yayınevi

Tekeli, İ., (1972). Bölge Planlama Üzerine, İTÜ Mimarlık Fakültesi Yayını, İstanbul.

Tüylüoğlu, Ş. ve Karataş, D. N. (2006). Bölgesel kalkınma ve ekonomik durgunlaşma süreci: Zonguldak örneği. Amme İdaresi Dergisi, 39(4), s.224. 